\title{
10. SEEING THE UNSEEN THROUGH THE FEMINIST MUSEUM HACK
}

\section{INTRODUCTION}

The oppressed must see examples of the vulnerability of the oppressor so that a contrary conviction can begin to grow within them. (Freire, 2000, p. 64)

I teach a course on culture and adult education and I begin by asking the students to name five male and then five female artists. Monet, Van Gogh, Dali, Picasso, Gauguin and more come easily for the former whilst eyes cast downward and silence meets the latter. Save gender, I set no parameters yet the students visualize 'Europeans', 'famous' and 'painters'. Activities on 'historical figures' yield similar results. What is responsible for creating such limitations to our cultural, social, political, historical, and aesthetic world?

The education system is one answer but another, and the focus of this chapter, is art galleries and museums (hereafter simply 'museums'). Whether one frequents them or not, these ubiquitous cultural institutions have the power to produce, shape and "mobilise representations of the world past and present [telling us] what the world is, or should be" (Hall, 2013, p. 127). Feminist cultural theorists Carson and Pajaczkowska (2001) refer to representations as 'the seen', and they are powerful because sight more than anything else is "considered evidence, truth and factual" as it establishes "a particular relation to the reality in which a visual is considered" (p. 1). Therefore, what we see, and are shown, and the settings of seeing and showing such as the authoritative context of the museum, produce reality. Carson and Pajaczkowska also draw attention to the relationship between the 'seen' and the 'unseen', with the former acting as a façade "to an underlying and unseen system of meaning" that has implications ranging from aesthetics to identity (p. 1).

Deconstructing the seen to unearth the unseen systems of meaning that perpetuate gender injustices has been a preoccupation of feminist cultural researchers for decades. As a feminist adult educator and researcher with one foot in museums and the other in gender justice and change, creating a pedagogical activity to operationalize pedagogically and investigate methodologically the unseen has been my aim. I have taken to heart Plantenga's (2012) challenge to design "tools to analyse the underlying systems of power that institutionalise and manipulate identities in ways that justify oppression, discrimination and often violence" (p. 29). Manicom and Walters (2012, p. 4) too call for new "pedagogies of possibility ... grounded in pragmatic 
assessment" - in my case interrogating the narratives, displays and images of the museum - and the imagination, the capacity to think critically, reflexively, and to act creatively, innovatively and radically "once prevalent relations of power are made visible". My response is the Feminist Museum Hack, a method that stimulates the power of seeing - the oppositional feminist gaze - to render visible and disrupt the unseen power of patriarchal knowledge making in the visuals and texts of museums.

In this chapter, I discuss the Feminist Museum Hack as a fluid pedagogical, methodological, analytical and interventionist practice aimed to educate, investigate, interrogate and dislocate unseen practices of gender and its intersectionalities. I ground my discussion in theories of representation because central to museums, as Hall (2013) and hooks (1995) remind us, is the practice of 'representation', "a crucial location of struggle for exploited and oppressed people asserting subjectivity and decolonisation of the mind" (hooks, 1995, p. 3). Using examples, I outline various components of the Hack, illuminating its contributions to feminist adult education as an embodied educational and grounded research practice that encourages critical analytical assessment, visual literacy, new knowledge creation and the imagination. The Hack exposes the privileged discursive and visual authority of the museum, what Freire (2000) in the above quotation calls "vulnerability", and patriarchal ideology that hides in plain sight to re-enforce and maintain a gendered status quo.

\section{MUSEUMS, REPRESENTATION AND GENDER}

Conn (2010) believes "we live in a museum age. At the turn of the twenty-first century more people are going to more museums than at any time in the past" (p. 1). Pedagogy is installed in the armoury of these major culture institutions, and they radiate authority and legitimacy through assumed impartiality, objectivity, and neutrality. As a result, art and cultural institutions are some of the most trusted knowledge legitimating institutions in society (e.g. Hannay, 2018; Janes, 2015). I would argue that if museums are representing society, culture, history or identity in all their complexity and contradiction, as some are, then this high degree of 'trust' is crucial to creating forms of knowledge and understanding about people and the world that could bring about justice and change. However, many museums remain elitist, colonial, racist and sexist (Marstine, 2006). Shaped through ideologies of power manifest in practices of representation such as lighting and positioning (stagecrafting), language (discourse) and images, museums show us and tell us what counts as knowledge, what has aesthetic value, what history matters, what gender is normative and superior (Bergsdottir, 2016; Hall, Evans, \& Nixon, 2013; Whitehead, 2009). Rogoff (2013) challenges us to learn to question actively "who we see and who we do not see; who is privileged within the regime of specularity ... whose fantasies of what are fed" (p. 15) through the stories museums and art galleries show and tell. The questions are 'how' do we do that and why bother?

Museums are important because they are ubiquitous, the personification of what Giroux (2004, p. 62) called circuits of "power, ideologies, and values" (p. 62) found 
worldwide. They play a strong 'public pedagogy' role, producing meaning through clever institutional practices. These are practices of representation and according to the Oxford English Dictionary, "to represent something is to describe or depict it, to call it up in the mind by description, portrayal or imagination" (cited in Hall, Evans, \& Nixon, 2013, p. 2). For Hall et al. (2013) representation is one of the most powerful practices of our time. He theorizes representation in three important ways that are applicable to museums. The first he calls the 'reflective'. Does what museums show and tell simply 'reflect' what "already exists out there in the world?" (p. 1). The second is 'intentionality'. Do we accept curatorial statements or artworks simply as expressions of what painters or the curators intend, or are there other valid interpretations? These harken back to notions of trust, validity and legitimacy, and challenge us to think about both museum 'statements of fact' and in particular, the 'gaze'. Hall's third theorization of representation is 'constructivist', how representations 'construct' meaning and their implications. Representations are not simply a collection of inert 'things' - objects artefacts or artworks - they are narratives, discourses, metaphors and imaginaries that produce, exchange and actively shape ways of seeing and knowing. Through organizing, clustering, arranging, classifying, displaying and naming, culture in museums exercises "power over how people think of themselves and their relationship to society and to others" (Giroux, 2004, p. 62). While museum representations "bear a close resemblance to the things to which they refer they ... carry meaning and thus, have to be interpreted" (Hall, 2013, p. 5). But museums operate through what Gramsci (1971) called unforced, tacit consent, lulling both men and women into accepting, for example, that "creativity is an exclusive masculine prerogative and that as a consequence, the term artist automatically refers to man" (Pollock, 1988, p. 29). Burnham and Kai-Kee (2011) suggest that 'passive reception' of artist and curator intentions, transmitted through authoritative statements and chosen objects, lies behind this. And both unconsciously and by design this contributes to visual 'illiteracy', the inability to 'read' representations beyond the 'god voice', and therefore, the inability to make the institution accountable for what it shows and tells and its impact on how we see and understand.

While Hall (2013) addresses representations of colonialism and the 'other' in museums, feminist cultural theorists point out their highly patriarchal and sexist natures (Pollock, 1988). Patriarchy is cultural - knit into the fabric of society and upheld by individuals and institutions, a "central feature that reinforces racism, classism, homophobia, transphobia, nationalism, ageism, and ableism in our daily lives" (Ayu Saraswati, Shaaw, \& Rellihan, 2018). Representation is what we see, are able to see, or are "allowed or made to see" about women and gender and this ranges from total absence to under-representation, from over-simplification to stereotyping (Rose, 2001, p. 6). Representations are refracted through 'the male gaze' in ways that has colonized the female body, and naturalized hegemony in hierarchies of masculinity and femininity (Bloom, 1999; Marstine, 2006). For Pollock (1988) representations are 'signifiers', women, and the 'signified', a femininity of fragility, 
dependency, incapacity, and inactivity to "act as a foil to the masculine usurpation of activity, productivity [and] creativity" (p. 136). Indigenous scholars Penn Hilden and Lee (2015) add to this, illustrating the lack of Indigenous women's stories in museums as well as the 'Pocahontas loop', representations of Indigenous women as either victims of colonialism or idealized "tough femininity" both of which render them history-less, voiceless and powerless. The categorization of 'woman' in museums is thus "shot through by other categories of social identity such as ethnicity" (Lazar, 2005, p. 1). Representations of women, to return to Hall's theorizing, is a process that excludes or essentializes (reflects dominant culture) and engenders ways of seeing through the male gaze (intention). This limits views of women as human beings who have made important contributions to society, culture, politics, history and aesthetics. There are of course exhibitions that have re-framed and renarrated history through a feminist lens. For example, fashion history is mostly told 'neutrally' or through the lens of the god-like figure of the male courtier (e.g. Dior). Yet an exhibition entitled Victims of Fashion at the Bata Shoe Museum in Toronto illustrated the brutality inflicted upon women through toxic pigments, body-bending corsets and flammable fabric (e.g. Clover, Sanford, Taber, \& Williamson, 2018). But for the most part, I, my colleagues and Hack participants have found in the hundreds of museums hacked over the past years, that masculinized constructions, stereotypes and absences remain steadfast.

\section{THE FEMINIST MUSEUM HACK}

The unrepentant sexism and its problematic invisibility in museums justifies the creation of more dissonant and creative feminist adult education approaches to teach and learn about gender (in)justice within museum and art galleries. Indeed, Obrist and Raza (2015) remind us that "unsatisfying conditions" like these in museums can be excellent catalysts to incite "the imagination of possibility" (p. 2). In collaboration with colleagues, I have created the Feminist Museum Hack to challenge the many problematic representations of women and gender. Like many other adults, I lacked the ability to examine critically texts, paintings and collections and therefore, saw nothing amiss (Burnham \& Kai-Kee, 2010, p. 19). This mean I could not leave 'learning' about their power to individual interpretation. I had to be what Martin (2003) called 'intentional' because gender injustice is intentional. I was also finding, along with other feminist adult education scholars, that my students, and many museum educators, lacked gender consciousness (e.g. Clover \& Sanford, 2016). "Has equality not been reached?", many students have queried. "Isn't feminism passé in this post-modern world? No to both as \#Metoo has shown. The Hack is a way to ignite their appetites for the feminist project and instil 'legitimate rage' at the all but undiminished persistence of patriarchy. Rage itself does not produce change, Martin (2003) reminds us, but it is where there is hope. "And of course, making anger hopeful is an educational task" (p. 575, emphasis in original). 
Despite all the important practices of feminist adult education, I could not find one that was applicable to what I was seeing and reading - the scripto-visual in museums and therefore, I had to create one. The Feminist Museum Hack is a means to penetrate and illuminate critically and creatively the male gaze, the seen and unseen gender formations secreted in the dioramas, artworks, displays, and language. I liked the verb 'to hack' because it means to enter subversively, without 'authority' or 'authorization'. Museums do not willingly invite me/us in to reveal what they conceal and challenge their authority. The aim of the Hack is primarily to encourage a radical feminist oppositional gaze and imagination capable of unravelling and re-weaving the museum's fabric of ideological restrictions. It can be likened as well to Mohanty's (1989, p. 208) 'practice of resistance', “conscious engagement with dominant, normative discourses and representations" through an oppositional analytic. The Hack also encourages direct agency in the form of disrupting physically the visual and narrative detachment of images and narratives to reveal the museum's politics but also, its vulnerabilities and thereby, shatter its authority to dictate the past and the present. Another central aspect of the Hack is that it is fluid and adaptable to different museums - art, ethnographic, textile, military, war, doll, industrial, shoe and so forth - although there are many commonalities across these institutions.

Before I discuss the Hack in more detail, let me establish some parameters and ideas for future development. Women's museums exist, but I do not take these up in this chapter. I confine my discussions to museums that pretend to be gender neutral. Secondly, I confine my discussions to museums in England and Canada, although I have hacked museums in Europe and India with similar results. Thirdly, there is an increase of 'virtual exhibitions', but I have not yet applied the Hack to these as I prefer to be engulfed in the physical structures which tell a more holistic tale of gender exclusion than any single exhibition can.

\section{Frequency of Visits and Levels of Trust}

In line with research practice, I begin each Hack by asking the participants whether or not they have frequented museums and establish their level of trust in these institutions. I have also put myself and colleagues through this exercise. Janes (2015) observations above, that trust in these institutions is high, is accurate. Although I, my colleagues and the majority of the participants have frequented museums, and even the museum we are about to enter, few of us can offer substantive critiques save things like "I find it a bit dark", "it has a lot of "stuff"" or "it is large and I tire trying to see it all". When I query how we 'know' what the museum shows and tells us is true, few query 'truth' and most state, which reflects my own experience, that from what they have seen, nothing has suggested otherwise, although my question does raise suspicions, as it is meant to.

I remind the students that none of them is either un-intelligent or unconscious, as this can be an assumption, for I admit to making it about myself when I began finally 


\section{E. CLOVER}

to 'see' what had been unseen. It is not ideal for intelligent people to be 'fooled', but museum ideological obfuscations are cleverly done, perhaps even unconsciously done, but either way, they "sap power, to take power" (Foucault, 1982, p. 142).

\section{Quantitative Questioning, Space and Time}

I include in the Hack simple yet telling quantitative 'count' questions: How many stories are about women and how many about men? How many artworks are by women and how many are by men? The is an easy way to begin what feels at first like a daunting task and gives a first glimpse into the 'unseen'. If not for paintings by Emily Carr, for example, the National Gallery of Canada would be nearly devoid of women's works. This quantitative 'snapshot' is enough to begin to raise the hackles of participants - the rage behind hope - who had never seen this show of absence, before.

Adding to this, simply counting women's works does not tell the entire story of gender inequity and therefore, we also count numbers of works or displays by/ about Trans-women, lesbian, Indigenous, working class, Black, or differently abled women. This complicates and expands our discussion of gender and allows us to explore the complexity of identity, or their absences, in the world shaped by the museum, which is shaped by the patriarchal beyond its walls.

Building on this, The Feminist Hack focuses on questions of permanency and temporality in terms of exhibitions. How many permanent exhibitions are by or about women and how many of the temporary? What do permanence and temporality say to museum visitors? In conversation with a curator in a museum in England following a hack he pointed out "the museum has little control over what it owns as a permanent collection and therefore, nothing can be done about it". While the former is true, many artworks and objects are donated, and mostly by male collectors. Malt (2006) points out, the latter is not because it does have control over what it 'says' about its permanent collections and I will return to this later.

\section{The Question of Framing}

Building on the above are questions of how women are 'framed' because this can take us deeper into differences, but it can also reveal commonalities. For example, we began by questioning whether or not the Becoming BC (British Columbia) exhibition at the Royal British Columbia Museum was framed within a discourse of colonialism. The answer is both yes and no. It is all about colonialism, a representation of discovery and progress, but it neither acknowledges nor questions this. Therefore, how Indigenous women are portrayed and any exploration of their sense of agency to tell their own stories, is practically null and void. Indigenous women are simply too irrelevant, save a mention or two of marriages to explorers, to be included in the grand colonial narrative of male conquest. What of Settler women? We found they only existed as wives, and almost all were nameless and story-less. There were, 
however, a number of stand-in 'representations' in the forms of dainty tea services, linens and fans. We thus unearthed how Settler women were absented, save through an essence of domesticity, class, and female propriety, which matched the 'elegance' (museum words) of the uniforms of the 'named' and storied, male explorers. The Becoming $B C$ exhibition has sanitized the plundering, murdering and displacement of the colonial project, and excluded or silenced women through an imaginary of femininity. Revealing this makes students very angry indeed and I often view them stomping from one display to another, pointing vigorously to what can now be 'seen'.

Taking it further, a display which at first appeared to be about women's activism around abortion rights in a museum in Ottawa, turned out to be the story of physician and advocate Henry Morgentaler. While he was a very important figure in reproductive health in Canada, the Feminist Museum Hack illuminated two things. Firstly, museums defer to 'individual' and 'heroic' narratives and these for the most part, are stories of individual men. We discuss here how they form the discursive base of 'leadership' and 'change-makers'. Women's actions of leadership for change are most often collective, and therefore, to 'ill-defined' to include. Secondly, women's stories are important when in relation to men. This is clear in the example above, but it is ubiquitous. In an art museum in England, the male artists were described in terms of innovation and brush stroke, whilst the female artists were described as wives or daughters of famous men, instilling an idea of 'dependency' which may in fact be true, but where did it come from and how do we lay waste to it?

The physical space of the museum is also an important 'framing' device that is not overlooked in The Feminist Museum Hack. How are displays about women and men positioned in the museum and what does this say to us visually? My partner and I found an exhibition of the suffragette movement in Manitoba placed in a poorly lighted hallway, where it would be easily missed. Even more infuriating was sitting atop an original petition, with hundreds of signatures by women and some men in favour of 'votes for women', was a small comedic figurine of a gaggle of geese. In another museum, a lowly lighted diorama of a woman's sitting room at eye level juxtaposed an elevated, brightly lighted display of male uniforms and weapons.

\section{Interrogating the 'Scripto-Visual'}

Central to feminist visual culture is the 'scripto-visual' what we take up as a combination of imagery, curatorial statements, myths, metaphors and symbols. While reading images is central to art history, it is not for many other disciplines. To teaching students to unpick the meanings in artworks, the Hack draws directly from feminist visual culture but it also operationalizes it pedagogically, rather than simply as a research method. A question in point here is: What are the women doing in the artwork? How are they positioned in relation to men? What is the central story being told and how? Students see in forest scenes by 'the masters', for example, women draped naked over branches, whilst the men sit fully clothed in intellectual discussion. "The story is that women are adornments to men who contemplate", was 
a comment by a particularly disappointed female student who had frequented the museum but had never thought about the messaging and its implications.

Another part of scripto-visual analysis is to expose the hidden "relationship between language and ideology" (Pollock, 1988, p. 29). We considered one diorama entitled Men, animals and machines: Farming meant combining their power. Contrary to the signage, the human images are women labouring in a field. Although women were and remain active farm workers, they are seldom referred to as farmers and this representation simply re-enforces that message. Indignation was apparent in this question written on a post-it note by a student and attached to the image: "So what are they then, animals or the machines?"

\section{Disruption and Agency}

This mention of the 'post-it note' brings me to a final aspect of the Feminist Museum Hack, what Bannerji, Carty, Delhi, Heald and McKenna (1991) call "direct agency" (p. 77). For us, this a visual force of re-writing and challenging the museum's hegemonic patriarchal representations. We move through the collections attaching post-it notes to display cases, beside artworks and so forth, that carry provocative questions and highlight omissions, such as why the only mention of women in a replica of old China Town is 'prostitutes' or make suggestions: "Since this violence is clearly a story of male power, just say it". We have also used coloured dot stickers to identify works by women or men, creating a visual map of gender imbalances. Green painter's tape works well to create a visual redaction of sexist language. Following the hacks, we create skits and particularly, write poetry because as Lorde argues, the poetic voice is a powerful means to overcome "the intolerable or incomprehensible to find the strength and courage to see, to feel, to speak, and to dare ... institutional dehumanisation" (cited in Golding, 2013, p. 91).

Impacts of our interventions on visitors range from indignation at the "defacing" of the institution and 'mansplained' history lessons, to statements such as "Oh, you are not taking those [post-it notes] down? They had added so much to my visit. They have really made me think". These are important learning moments, opportunities to reflect on the challenges we continue face, as well as the potential of our work, as well as what museums could have if they were to change. The length of time our interventions remain depends upon partnering with a museum educator, who can ensure they stay for several weeks. Educators can also present the reports from our findings to curators and administrators. We deliberately make suggestions that require little financial cost such as inserting provocative questions about women in curatorial statements or changing sexist language. For the most part, these institutions do not seem to appreciate the challenge to their authority as no changes have been made. This is a limitation to the Hack on one hand, but on the other, it reveals the resiliency of patriarchy and the power to name and shape the world. 


\section{FINAL THOUGHTS}

Culture, Hall (2013, p. xxi) reminds us is a "constitutive process, as important as the economic and material base" in shaping and mobilizing subjectivity, and knowledge. For me, this is what makes cultural institutions like museums such important sites for feminist adult education teaching, learning and research. I have designed The Feminist Hack as a fluid, adaptable and embodied process that critically and creatively brings to light museums' patriarchal system of meaning, that hides in plain sight to limit seeing and understanding. The Feminist Hack is important because as an intentional project, it broadens the intellectual endeavour of reading the world, developing an informed visual literacy that acknowledges the significance of how the micro of the museum plays into and off the macro of gender and other hegemonies. As it illuminates the 'monocultures' of museums, it encourages new conversations about the missing histories of women enabling the next generation to inherit a strong sense of the practice of silencing. As we move through the galleries, we complicate spectatorship as an act of passive consumption, disrupt the complacency of normative assumptions, and illuminate the sleight of hand of stereotyping and essentializing. We develop our feminist oppositional gaze, and our imaginations because "imagination is the most subversive thing a public can have" (Mohanty, 2012, p. vii). I am conscious a great deal more work remains to be done, but for now The Feminist Hack is an important counter constitutive process to make the road of gender justice and change.

\section{REFERENCES}

Ayu Saraswati, L., Shaaw, B., \& Rellihan, H. (2018). Introduction to women's, gender and sexuality studies: Interdisciplinary and intersectional approaches. Oxford: Oxford University Press.

Bannerji, H., Carty, L., Dehli, K., Heald, S., \& McKenna, K. (1991). Unsettling relations: The university as a site of feminist struggles. Toronto: Women's Press.

Bergsdóttir, A. (2016). Museums and feminist matters: Considerations of a feminist museology. Nordic Journal of Feminist and Gender Research, 24(2), 126-139.

Bloom, L. (Ed.). (1999). With other eyes: Looking at race and gender in visual culture. Minneapolis, MN: University of Minnesota.

Burnham, R., \& Kai-Kee, E. (2011). Teaching in the art museum: Interpretation and experience. Los Angeles, CA: The J. Paul Getty Museum.

Carson, F., \& Pajaczkowska, C. (Eds.). (2001). Feminist visual culture. New York, NY: Routledge.

Clover, D. E., \& Sanford, K. (2016). Knowing their place: Feminist perceptions and understandings of women adult educators in museums. Journal of Adult and Continuing Education, 22(2), 117-133.

Clover, D. E., Sanford, K., Taber, N., \& Williamson, S. (2018). Feminist interrogations and creative teaching in art galleries and museums. In R. McGray \& V. Woloshyn (Eds.), Proceeding of the 37th Canadian Association for the Study of Adult Education Conference (pp. 36-42). Regina: University of Regina.

Conn, S. (2010). Do museums still need objects? Philadelphia, PA: University of Pennsylvania.

English, L., \& Irving, C. (2015). Feminism in community: Adult education for transformation. Rotterdam, The Netherlands: Sense Publishers.

Foucault, M. (1982). The subject of power. In H. Dreyfus \& P. Rabinow (Eds.), Michel Foucault: Beyond structuralism and hermeneutics. Chicago, IL: University of Chicago Press.

Freire, P. (2000). Pedagogy of the oppressed (30th anniversary ed.). London: Bloomsbury Academic. 


\section{E. CLOVER}

Giroux, H. A. (2004). Cultural studies, public pedagogy, and the responsibility of intellectuals. Communication and Critical/Cultural Studies, 1(1), 59-79.

Golding, V. (2013). Museums, poetics and affect. Feminist Review, 104, 80-99.

Gramsci, A. (1971). Selection from prison notebooks (Q. Hoare \& G. Nowell Smith, Eds.). New York, NY: International Publishers.

Hall, S. (2013). Introduction. In S. Hall, J. Evans, \& S. Nixon (Eds.), Representation (pp. xvii-xxvi) London: Sage.

Haiven, M., \& Khasnabish, A. (2014). The radical imagination. London: Zed Books.

Hannay, C. (2018, September 15). Canadians visiting museums, galleries more than ever, survey shows. Globe and Mail. Retrieved Mars 20, 2019, from https://www.theglobeandmail.com/canada/articlecanadians-visiting-museums-galleries-more-than-ever-survey-shows/

hooks, b. (1995). Art on my mind. New York, NY: The New Press.

Janes, R. (2015). Museums without borders. London: Routledge.

Lazar, M. (2005). Critical feminist discourse analysis: Gender, power, and ideology in discourse. London: Palgrave-Macmillan.

Malt, C. (2006). Women, museums and the public sphere. Journal of Middle East Women's Studies, 2(2), $115-136$.

Manicom, L., \& Walters, S. (Eds.). (2012). Feminist popular education in transnational debates: Building pedagogies of possibility. New York, NY: Palgrave Macmillan.

Marshment, M. (1993). The picture is political: Representation of women in contemporary popular culture. In D. Richardson \& V. Robinson (Eds.), Thinking feminist (pp. 123-150). New York, NY: Guildford Press.

Marstine, J. (Ed.). (2006). New museum theory and practice. Oxford: Blackwell Publishing.

Martin, I. (2003). Adult education, lifelong learning and citizenship: Some ifs and buts. International Journal of Lifelong Education, 22(6), 566-579.

Mohanty, C. (1989). On race and voice: Challenges for liberation education in the 1990s. Cultural Critique, 14, 179-208.

Mohanty, C. (2012). Foreword. In L. Manicom \& S. Walters (Eds.), Feminist popular education in transnational debates: Building pedagogies of possibility (pp. vii-x). New York, NY: Palgrave Macmillan.

Obrist, H., \& Raza, A. (2015). Ways of curating. New York, NY: Penguin Random House.

Penn Hilden, P., \& Lee, L. (2010). Indigenous feminism: The project. In C. Suzack, S. Huhndorf, J. Perreault, \& J. Barman (Eds.), Indigenous women and feminism: Politics, activism, culture (pp. 56-77). Vancouver: UBC Press.

Phillips, R. (2011). Museum pieces: Towards the indigenization of Canadian museums. Montreal: McGillQueen's University Press.

Plantenga, D. (2012). Shaping the magic: Reflections on some core principles of feminist popular education. In L. Manicom \& S. Walters S. (Eds.), Feminist popular education in transnational debates: Building pedagogies of possibility (pp. 25-40). New York, NY: Palgrave Macmillan.

Pollock, G. (1988). Vision and difference: Feminism, femininity and the histories of art. London: Routledge.

Rogoff, I. (2013). Studying visual culture. In N. Mirzoeff (Ed.), The visual culture reader (3rd ed., pp. 14-26). London: Routledge.

Rose, G. (2001). Visual methodologies. London: Sage.

Whitehead, C. (2009). Museums and the construction of disciplines: Art and archaeology in nineteenthcentury Britain. London: Gerald Duckworth \& Co. 